\title{
Effective Way and Method of Education through University-Enterprise Cooperation Based on University-Enterprise Benefit Community
}

\author{
Zhaonan $\mathrm{Mu}$ \\ Guizhou University of Commerce, Guiyang, Guizhou, 550001, China
}

\begin{abstract}
Keywords: University-enterprise cooperation, University-enterprise benefit community, Higher education, Talent training, Way
\end{abstract}

\begin{abstract}
University-enterprise cooperation is the contemporary value orientation of Chinese higher education in the reform of quality-oriented education and the deepening of adaptation to social rhythm development It allows social enterprises and schools to cooperate and cultivate applied skilled talents meeting social demands and meanwhile promotes development transformation of regional economic society. Currently, the new concept of "benefit community" has been put forward in university-enterprise cooperation, which diversifies ways of talent training in colleges and universities, fully arouses the initiative of enterprises and finds a coherence point of interest demand between enterprises and schools. This paper discusses problems of university-enterprise cooperation in actual higher education and the realized teaching mode in detail based on the educational concept and proves the effectiveness and sustainable development of education through university-enterprise cooperation in higher education.
\end{abstract}

\section{Introduction}

Concepts of "university-enterprise cooperation" and "university-enterprise benefit community" have emerged in the current period with economic situation under transformation and industrial upgrading. Due to urgent needs for a lot of high-quality talents with high application efficiency in the society, the Party specifically pointed out in the $3^{\text {rd }}$ Plenary Session of the $18^{\text {th }}$ Central Committee of the Chinese Communist Party, "it is required to deepen industry-education integration and university-enterprise cooperation positively and cultivate high-quality laborers and skilled applied talents good for the development of social enterprises.” Therefore, university-enterprise cooperation tends to take the path of "benefit community" as it can not only find common interest points between colleges and enterprises, but also have positive advantages for talent training in colleges and universities.

\section{University-enterprise benefit community}

Reasons for establishing university-enterprise benefit community. Talent training of higher education has tended to be open gradually since the comprehensive implementation of quality-oriented education in China. With the constant development of national economy and constant expansion of technical fields of enterprises, there are more and more urgent needs for "plug and play" technical talents. Therefore, university-enterprise cooperation becomes a win-win mode for talent transmission to the society and talent selection by enterprises. However, according to the practical situation, Chinese university-enterprise cooperation has great deficiencies in cooperation depth and width. Moreover, enterprises lack initiative and enthusiasm. Therefore, how to find a coherence point of interest between enterprises and schools becomes the key to be studied in the current university-enterprise cooperation mode.

Fragmentation of university-enterprise cooperation

China has implemented quality-oriented education for over 20 years. However, under the influence of rooted concepts in traditional education, colleges and universities still focus on theoretical teaching in university-enterprise cooperation projects. The implementation of practical teaching is single in terms of both mode and contents. In addition, teaching contents and practical cooperation fail to be linked, thus causing unsmooth teaching process. In essence, though 
university-enterprise cooperation has been implemented, it has undeserved reputation in fact as relevant educational objectives, laws and regulations and sustainable development plan are not made based on university-enterprise cooperation and original intention of university-enterprise cooperation in talent cultivation requirements is not realized.

Surfacing of university-enterprise cooperation

The reason why university-enterprise cooperation is short-term is that both parties fail to chime in easily or find the so-called coherence point of common interests or they have inconsistent orientation for talents cultivated. According to the practical situation of some university-enterprise cooperation in the society, many cooperation projects fail to take internal needs into consideration and most of them are face-saving projects. This indicates that both parties do not have any strong and purposeful cooperative motivation. Such university-enterprise cooperation cannot find any motivation and initiative for further development in the long run, nor there is any common interest.

The essence of university-enterprise cooperation can be seen according to the above. If universities and enterprises fail to achieve win-win benefit or have common development demands, there is no significance for cooperation. This violates economic development law of the contemporary society. It not only wastes the precious time of enterprises, but also is adverse to future development of college students. Therefore, the objective of establishment of benefit community between universities and enterprises should be to form a mutually beneficial win-win mechanism. Moreover, they should serve each other, reach consensus on economic benefit, technical research and educational mode and establish a long-lasting and deep cooperative relationship. This is the reason for the establishment of university-enterprise benefit community.

Review on connotations of talent training with university-enterprise benefit community under the background of industrial economic transformation and upgrading. China is in the period of industrial economic transformation and upgrading when enterprises have urgent needs for college talents. For the establishment of university-enterprise benefit community, it is required to review connotations and feasibility of talent training. The author thinks that this community should realize the following:

\section{Integration of talent training objectives}

Currently, conditions of social economy change quickly. To cooperate with enterprises for talent training, colleges and universities should first know the dynamic state of enterprises. Meanwhile, enterprises should get acquainted with the composition of educational system of universities positively. It is required to strengthen the rational construction of top-level design of educational mode with joint efforts of both parties under the environment of talent cultivation with benefit community and seek for internal relation between enterprise demands and talent training law of colleges and universities so as to adjust and optimize professional talent training objectives appropriately in good time, finally meet enterprise demands for talents and promote sustainable development of college education. Therefore, the educational mechanism under the mode of university-enterprise benefit community is a brand new orientation for the development of higher education in China. It fully reveals comprehensive, technical and innovative features of talent training objectives of colleges and universities, which form completely based on top-level design of university and enterprise, and allows both parties to achieve value convergence in talent training and demand.

Integration of teaching resources

Practical training base is a good carrier of education through university-enterprise cooperation. Its establishment aims at making universities and enterprises pursue for harmonization and resource value of talent training constantly from the perspective of common interest. Therefore, the integration of teaching resources refers to wider and more rational integration of teaching contents and enterprise factors into talent training mechanism of colleges and universities for the purpose of expanding university-enterprise cooperation space, realizing resource linking and enriching diversified cooperation. Cooperative education of university-enterprise benefit community aims at producing agglomeration effect through large-scale systematic cooperation in teaching contents, carrier, project, 
conditions and teachers so as to achieve new process and technology. This is the due gesture of transboundary education of university-enterprise cooperation.

\section{Integration of teaching process}

Colleges and social enterprises deepen teaching contents to train talents based on the combination of learning with working. This is an integration decision made for further satisfying industrial transformation and upgrading. A rich organization mechanism is established for student talents; realistic booster force is found for the improvement of students' professional skills and contents and connotations of the combination of learning with working is constantly enriched in the process of students' learning practice through university-enterprise cooperation. Therefore, it can be seen that education through university-enterprise cooperation is completely based on the integration of teaching process. It innovates talent training mechanism and mode through the integration of teaching contents, allows enterprises to participate in the whole process of talent training in colleges and facilitates rational talent selection of enterprises.

Integration of education and university-enterprise service

The platform of education through university-enterprise cooperation based on talent training in colleges and university-enterprise benefit community is a platform with the combination of industry, university and research as well as a platform serving students. It improves school-running functions of colleges and universities and realizes the function of regurgitation-feeding through services. It is a further strengthening of education through university-enterprise cooperation. According to the status of development of social enterprises, colleges and universities can gradually expanding pertinent training for talents in relevant industries through the establishment of various training plans, the development of new course and new teaching mode for the integration of education and university-enterprise service. In addition, students should be encouraged and guided to participate in more on-campus and off-campus scientific research projects so as to train their awareness of innovative service. Therefore, the educational mode of university-enterprise cooperation based on university-enterprise benefit community not only trains talents, but also realizes interactive integration of talents and social service ${ }^{[1]}$.

Effective way of education through university-enterprise cooperation based on university-enterprise benefit community in some college. University-enterprise cooperation is a long systematic process requiring patience and time for colleges and enterprises. In this process, both parties should endeavor to highlight their school-running and enterprise features, strengthen cooperative mechanism constantly and accumulate experience. More importantly, it is required to learn more and make self-innovation in the process of talent training and make bold attempts on the basis of improving university-enterprise cooperative mechanism and expanding practical training platform. This paper introduces two talent training modes based on benefit community in some college and expects to make constructive suggestions for colleges and universities operating or preparing to operate educational mode through university-enterprise cooperative mechanism.

Construction of " $1+N$ " dual platform course system

Some college is a professional college. Therefore, its vocational education provides talents for the society directly. However, this college has established a thought, i.e. all objectives of educational mode through university-enterprise cooperation cannot be limited to employment, as it is aware that the essential function of vocational education is to explore potentials of humans and promote their all-round development. Therefore, in order to pay more attention to students' academic development and employment prospect, this college has established " $1+\mathrm{N}$ " dual platform course system for students, in which " 1 ” refers to courses of professional general skills platform, i.e. all professional students participate in applied cultural courses such as psychology of success and employment planning. It mainly reflects the rigidity of courses and represents course knowledge to be mastered by all students. $\mathrm{N}$ refers to courses of post capacity platform mainly for students of different majors, posts and abilities, which include various requirements of enterprises for students which are also key contents to be learnt and emphasized by students in future work. It manifests the flexibility of this course system. Courses of professional general skills platform mainly cultivate students' 
cultural and professional basic abilities and expand their technical thinking mode and acceptance of occupation. This college sets courses of professional general skills lasting for two academic years.

Courses of post capacity platform reflect its diversification as "N" which can provide post capacity training courses for students in multiple majors, guide students to participate in technical courses and directly face employment posts. This course is completed in the third academic year and is mainly based on market and realistic demands of enterprises. It includes coaching for professional ability qualification obtainment of students, covers student employment planning contents illustrated by enterprises and manifests the flexibility of this course. To prevent students from being too closed in courses of post ability platform, this college also establishes "order class" education in the form of class team. "Order class" means that enterprises focus on training a batch of students in a class after observation and all teaching contents are determined jointly by university and enterprise. Enterprises provide certain conditions and environment for students in "order class" to complete some practical courses and even internship in enterprise. Finally, talents accepted by enterprises are selected through "order selection" mode. Such "order class" adopts the mode of small class teaching in this college. Compared to other classes, small class teaching has learning-working alternation mode provided by more specified enterprises. For example, "auto parts manufacturing” training class in the college adopts four-section cyclic learning-working alternation mode during 18 weeks in a semester, including 6 weeks for theoretical learning in school, 6 weeks for practical learning in enterprise, 2 weeks for assessment in school and 4 weeks for internship in enterprise. According to " $1+\mathrm{N}$ ” teaching concept of the college, this is a spiral progressive educational mode that can realize students' vocational abilities early.

Evaluation educational mode based on vocational qualification certification standard of enterprises

Automobile service major of Transportation Vocational Education Faculty of the college has implemented university-enterprise cooperation with multiple local motor corporations and 4S stores. The college has obtained special authorization and technical support of automobile manufacturers and sales companies through the cooperation. Technician training of automobile companies is included in automobile service specialized courses of the college. Students can participate in automobile service technical training activities of automobile companies of different brands and obtain corresponding technical qualification certificates through training practice, such as automobile repair qualification certification, automobile service industry qualification certification and automobile sales qualification certification. This is seamless connection between skill qualification of students majoring in automobile and corresponding technical grades of enterprises. Therefore, students can obtain employment post qualification or vocational qualification technical training certificate of an automobile company easily after graduation.

Moreover, the college establishes "school + 4S store + automobile manufacturer" evaluation mechanism for evaluating learning achievements of all students in order class, measures and selects students comprehensively based on evaluation result and graduation assessment, realizes diversified judgment over evaluation subjects and gives more opportunities to talents cultivated. Automobile manufacturers entrust a third party to investigate students in order class and know details of the educational level of students. Finally, manufacturers send an examination team to directly participate in graduation evaluation process of students in order class, set an examination process without the participation of teachers and only involving third-party supervision of manufacturers and realize examination-teaching separation mechanism of talent training.

\section{Conclusion}

According to the educational mode of university-enterprise cooperation based on university-enterprise benefit community, its directed training and apprentice mechanism accord with the fast-paced development of social enterprises and are the best way to respond to quality-oriented education and train plug-and-play talents. Talents trained based on this mode are more pertinent for the society. They have higher degree of cognition for the society and larger space for promotion and 
meet basic strategic requirements of the development of social enterprises. Therefore, university-enterprise cooperation should be the most effective mode for the maximization of educational functions in higher education in the future, which realizes win-win benefits and makes the future of university talents brighter. It has long-term constructiveness.

\section{References}

[1] Yang Ruixue. Exploration and Analysis on Ideological and Political Education in Higher Vocational Education Based on Talent Training Mode of Learning-Working Combination. Hebei Normal University, 2012.13-19.

[2] Bao Shen. Study on Practice of University-Enterprise Cooperation in Architectural Engineering Technology Major in Higher Vocational Colleges in China. Central South University, 2012.44-50.

[3] Qin Xingshun. Exploration and Practice of University-Enterprise Educational Mode Driven by Benefit Community. Vocational and Technical Education, 2013.11(20),44-46. 